Article

\title{
Finnish University Students' Views on Climate Change Education and Their Own Ability to Act as Climate Educators
}

\author{
Eija Yli-Panula ${ }^{1, *(\mathbb{C},}$, Eila Jeronen ${ }^{2} \mathbb{C}$, Salla Koskinen $^{3}$ and Sanna Mäki ${ }^{3}$ \\ 1 Department of Teacher Education, Faculty of Education, University of Turku, FI-20014 Turku, Finland \\ 2 Faculty of Education, University of Oulu, FI-90014 Oulu, Finland; eila.jeronen@oulu.fi \\ 3 Department of Geography and Geology, Faculty of Science, University of Turku, FI-20014 Turku, Finland; \\ salla.koskis@gmail.com (S.K.); sanna.maki@utu.fi (S.M.) \\ * Correspondence: eija.yli-panula@utu.fi
}

Citation: Yli-Panula, E.; Jeronen, E.;

Koskinen, S.; Mäki, S. Finnish

University Students' Views on

Climate Change Education and Their

Own Ability to Act as Climate

Educators. Educ. Sci. 2022, 12, 169.

https://doi.org/10.3390/

educsci12030169

Academic Editor:

Kyparisia Papanikolaou

Received: 2 December 2021

Accepted: 25 February 2022

Published: 28 February 2022

Publisher's Note: MDPI stays neutral with regard to jurisdictional claims in published maps and institutional affiliations.

Copyright: () 2022 by the authors. Licensee MDPI, Basel, Switzerland. This article is an open access article distributed under the terms and conditions of the Creative Commons Attribution (CC BY) license (https:// creativecommons.org/licenses/by/ $4.0 /)$.

\begin{abstract}
Climate change (CC) has widespread impacts on human and natural systems and thus threatens the future of contemporary youths. Only a few studies on climate change education (CCE) have been published in Finland, and no research has been conducted on upper secondary education. Thus, this study investigated Finnish university students' views on CCE in upper secondary schools. According to them, the most common goals in CCE are increasing and structuring knowledge, developing thinking skills, and encouraging action both today and in the future. The respondents considered preconceived notions and opinions stemming from their inner circles, the media, and social debate to be the most difficult factor in teaching about CC. CCE was perceived to provide either a weak or relatively weak capacity to follow a climate-friendly lifestyle. By increasing and diversifying teaching and strengthening multidisciplinarity, climate-friendly lifestyles can be improved. The respondents' views on current and future CCE differed most clearly concerning motivation and inclusion, which are not prevalent in contemporary teaching. The results indicate, however, that the university students were motivated to increase and develop CCE, and according their answers, their own capacity to address different aspects of CCE was relatively good.
\end{abstract}

Keywords: climate change education; university students; opinions of students' inner circle; mixed method approach

\section{Introduction}

In the fifth report of the Intergovernmental Panel on Climate Change [1], it is stated that THE human influence on the global climate system is clear and that current anthropogenic emissions of greenhouse gases are the highest in history. It is also stated that climate change (CC) has widespread adverse impacts on human and natural systems. CC is thus one of the most threatening issues for the future of contemporary youths. In order for young people to protect their future, they must be sufficiently informed about climate science and motivated to curb CC. Some studies have shown that young people are anything but enthusiastic about working on this issue and even less knowledgeable and motivated than adults [2,3], while other studies have found that leadership or other pro-climate activism has created a positive attitude among students towards climate action (Budziszewska, and Głódz, 2021 and Mac Kay et al., 2020 [4,5]). Education, teaching, and guidance are all ways to influence the knowledge, skills, values, and attitudes of people of all ages and, consequently, their behavior and thinking [6,7].

Interest in climate change education (CCE) has increased in recent years [8] for several reasons. First, CC is a complex issue to teach, as its consequences are reflected in both global warming and regional changes in temperature, rainfall, and wind, as well as rising ocean levels. Second, the concept of CCE is not well established. It has been referred to as, for example, climate education, and as a result, its purpose and goals can be difficult 
to conceive $[9,10]$. Third, even increased didactic knowledge has not provided a solution concerning how CC should be taught and what should constitute CCE [11].

In this study, CCE is understood, according to Anderson [8], as a component of environmental education and education for sustainable development. Its core concept is CC literacy, which means that students understand the scientific concepts related to CC and the relationships between them, as well as the effects of CC and their own activities on the environment. CCE is multidisciplinary and interdisciplinary. Multidisciplinary means that knowledge of various individual sciences is needed [12]. Interdisciplinarity, on the other hand, incorporates elements from a variety of disciplines and also integrates environmental, economic, social, and political issues [13]. Therefore, CCE should include information both on CC and other environmental issues, as well as economic and social issues such as pollution abatement and sustainable consumption and lifestyles [8].

The curricula of Finnish basic education (ages 7-16) and upper secondary education (ages 16-19) emphasize interdisciplinary cooperation and recommend student-centered active teaching methods $[14,15]$. CC and its ecological impacts are mentioned at a general level. As for subjects, CCE was long included only in the objectives and contents of basic education in biology, geography, and environmental knowledge and in those of upper secondary education in biology and geography, as well as in cross-curricular themes named sustainable development and global responsibility $[14,15]$. In the new upper secondary school curriculum introduced in 2021, CC is more comprehensively on the agenda [16]. As a subject between natural sciences and social sciences, geography supports the understanding of climate issues and the solution to these problems in particular (e.g., regional variation of CC impacts or regional planning for CC), as well as the use of geographic information systems (GISs) [17]. Most of the students had studied the curricula during their pedagogical study year.

CCE is challenging because many young people lack basic knowledge and understanding of CC [18-20]. There are also many misconceptions about the content of CCE [21-24]. CCE is also challenging due to the broad goals in curricula, and teachers have great latitude to use a variety of materials and exercises to meet these broad goals. Therefore, teachers may be confused and less knowledgeable in teaching about CC, and they may not cover the topic thoroughly. Thus, knowing how future teachers think about the curriculum and what they think about their skills in addressing CC is useful. Exploring views on CC and its underlying factors is essential, especially when considering that despite the widespread availability of information about CC, not all data sources are equally reliable [25].

Only a few studies on CCE have been published in Finland [9-11,26,27], and no research has been conducted thus far on CCE in upper secondary schools. Thus, we examined the views of university students about CCE in upper secondary teaching. The study was guided by the following research questions:

1. What kinds of views do Finnish university students have about the current state of upper secondary school CCE?

2. What kinds of views do Finnish university students have about the future aspects of upper secondary school CCE?

3. How do Finnish university students view their own abilities to promote CCE?

The results of this study were expected to contribute to developing and supporting CCE in teacher education. The development of the knowledge and teaching skills of future teachers concerning CCE is important because it will have a direct impact on learners' knowledge, skills, values, and attitudes related to CC and the achievement of CCE goals.

\section{Theoretical Background}

\subsection{Specific Features of Climate Change Education (CCE)}

For over a decade, the United Nations (UN) and the Education for Sustainable Development (ESD) program of the United Nations Educational, Scientific, and Cultural Organization (UNESCO) have played prominent roles in promoting sustainable development $[28,29]$. In sustainable development and education of sustainability, several different 
concepts (e.g., sustainable education, sustainability education, and education for sustainable development) have been and continue to be used. These terms contain similar ideas, but they do not mean the same thing [30]. Sterling [31] defined the term sustainable education as "a change of educational culture, one which develops and embodies the theory and practice of sustainability in a way which is critically aware. It is therefore a transformative paradigm which values, sustains and realises human potential in relation to the need to attain and sustain social, economic and ecological well-being, recognising that they must be part of the same dynamic".

The concept of sustainable education thus refers to finding sustainable solutions to environmental, social, and economic problems through education [32]. It is a concept that challenges both formal and non-formal educational sectors to actively participate in the creation of economic, social, and environmental programs that improve the quality of life, increase the empowerment of students to perform as active citizens, and respect interdependence [33].

Sustainability education is an interdisciplinary, collaborative, experiential, and potentially transformative process of creating a space for inquiry, dialogue, reflection, and action about the values and goals of sustainability [34]. Again, education for sustainable development is a holistic and transformational lifelong learning process which aims to enhance the cognitive, social, emotional, and behavioral dimensions of learning [35].

Climate change is an ecological phenomenon. CCE therefore requires a transformative education based on an ecological vision, with holistic, systemic, and multi- and interdisciplinary planning and implementation at its core. Sustainable education is built on this view, which is why it can be considered useful in the context of CCE.

The notion that CCE is crucial to redirecting teaching and learning in the face of the contemporary climate emergency is now widely established and accepted [36-39]. In this context, universities $[40,41]$ and teacher education departments [8] are of great importance in CCE.

According to Kagawa and Selby [42] (p. 4), the aim of CCE is to reflect in depth on what is very important and to envision future perspectives together. Education should increase holistic understanding of CC causes, consequences, and mitigation and adaptation measures [42] (pp. 241-243). To achieve this, critical and systemic as well as strategic thinking are needed. Critical thinking is a key skill on which systemic thinking is based [43]. Systemic thinking refers to the ability to understand the world as a complex system in which everything is connected to everything else [44]. This is an essential part of eco-social civilization, especially in identifying interdependencies and outlining causal relationships between ecological, social, and economic realities and their local and global dimensions [45]. Strategic thinking is crucial when creating viable strategies to implement solutions to environmental problems. It unites the knowledge, skills, and abilities needed to identify opportunities and formulate a vision on how to use those opportunities to solve a problem [46].

Increased knowledge of $\mathrm{CC}$ threats and other pertinent information concerning $\mathrm{CC}$ phenomena about the causes, processes, and consequences have caused young people to feel helplessness and environmental anxiety [46-50]. As in environmental education [51], the importance of emotional processing is also emphasized in CCE [9]. Through communality and working together [42] (pp. 241-243), CCE can foster feelings of empowerment and promote the development of action skills, providing opportunities for participation [52,53]. In addition, cooperation with individuals or groups outside the school or educational institution increases the effectiveness of CCE [11]. Climate-friendly behavior on the part of school or university leaders has also been found to strengthen the motivation and commitment of other members of the work community to achieve the goals of CCE [54]. In the literature, many authors [55-57] consider all types of behavior to be included in climatefriendly behavior. In CCE, from the perspective of the development of climate change mitigation behaviors, it would be important to discuss how the behavior of individuals would cause less change in global weather patterns. Issues to be discussed could be, for 
instance, energy conservation behavior, willingness to use or to select (or willingness to pay more) renewable energy, usage of environmentally friendly transportation, and the purchase of green products [58].

\subsection{Challenges of Climate Change Education (CCE)}

The challenges of CCE are affected by social, political, and educational perceptions. An example of those could be Unesco's 17 SDGs, which are politically drafted, may not always be the same, and are appreciated in all school and research societies. Societal value choices and the ways in which the media deal with conflicts between political interests and environmental problems impact the perceptions, attitudes, and values of both teachers and students, as well as perceptions about the division of responsibilities for action against the challenges posed by CC in the context of CCE [52].

From an educational perspective, the ever-increasing amount of knowledge and the inconsistencies between different data sources make it difficult to stay up-to-date and increase suspicion concerning research data related to CC [59]. Previous research has shown that teachers' and student teachers' knowledge of CC is incomplete, fragmented, and narrow, with many misunderstandings $[10,11,52,53,60,61]$. The multidisciplinary nature of CCE is also often perceived as challenging and even intimidating [11,62]. The implementation of CCE is often the responsibility of individual teachers [11,54]. Increasing multidisciplinarity is hampered by challenges in teaching staff collaboration, such as the epistemic starting points and the pedagogical perspectives of teachers in different subjects, which are not always easy to combine [61]. Addressing controversial issues such as CC can arouse strong opinions and feelings in both teachers and students and can therefore be an unpleasant experience for teachers especially [60-63]. Teaching topics about CC is also hindered by the lack of appropriate teaching methods [11,41] and teaching materials considered appropriate and functional [62]. One key challenge is that very little attention is still paid in teacher education to the development of CCE and teachers' competences in sustainability education, such as integrated problem solving, transformative learning, and learning or proactive competences [8,9].

Achieving the goals of CCE is obstructed not only by the challenges and obstacles associated with teachers and teaching but also by various factors affecting students and learning. Students' knowledge of CC has been found to be incomplete and to contain many misconceptions about, for example, the link between CC and other environmental problems, such as ozone depletion and environmental pollution [10,11,52,53,64]. Learning science-based knowledge is important to alleviate CC anxiety [51]. Students' feelings and attitudes related to CC also pose challenges to CCE. Unaddressed negative emotions can manifest as, for instance, denial of CC, anxiety, apathy, or hopelessness, making it difficult to address climate issues [26,62,64]. Ratinen and Uusiautti [65] found that mitigation knowledge of CC among Finnish female upper secondary students was better than among Finnish male upper secondary students. Yli-Panula, Laakkonen, and Vauras [66] showed with Finnish upper secondary students that the ability to learn about and solve CC issues is linked not only to topic knowledge but also to people's beliefs regarding the topic, a result congruent with those generated by Leiserowitz [67] and Poortinga et al. [68]. The research by Yli-Panula et al. [66] also revealed that upper secondary school students' academic achievements are influenced by the structure and certainty of knowledge, as well as by the justification of knowing studied in relation to CC, which are results that are in line with those of Cano [69] and Mason et al. [70].

The nature of CC also poses its own challenges for CCE. Compared with many other environmental problems, the effects of $\mathrm{CC}$ are broader, less directly visible, and much more gradual, which makes it difficult to perceive the problematic nature of CC [26,52]. Because of the holistic and multidimensional nature of CC, students can perceive the empowerment of the individual to be very limited [52,62]. In addition, the huge amount of information and contradictions related to CC can confuse and frustrate students [11,52,62]. All in all, CC is a controversial, multifaceted, and contextual concept and may not be easy to 
comprehend. For this reason, this study took into account what is provided in the Finnish national curricula for basic education (primary and secondary) [14] and upper secondary education [15] for teaching of CC at these school levels.

Community action by schools and educational establishments is essential for the development of CCE. This includes climate-responsible and climate-friendly activities and engagement by learners in shared goals [11,53,71,72]. Of particular importance is the development of critical thinking skills and the perception of the need to change attitudes, beliefs, values, and practices that are detrimental to the climate. Future education and future visions are considered essential for the empowerment of individuals. The inclusion of the principles of CCE in teacher education is important, as is the development of teaching methods that will better support different students. In addition, it is important to increase cooperation between various sciences and other disciplines.

\subsection{Climate Change (CC) in Finnish Upper Secondary Education}

In the Finnish school system, basic education (primary and lower secondary education) and upper secondary education follow the national core curricula and quality requirements $[73,74]$. These curricula form a continuum. Thus, education in one level is built on the previous level. Our respondents are also targeting different levels of education in their teacher studies. Some of them will be class teachers in primary schools, and some will be subject teachers in the lower or upper secondary schools.

The institutions providing education (mostly public, some private, and all free and accessible) and the individual teachers have, however, wide pedagogical freedom to choose the teaching methods and materials and to emphasize certain topics. However, all topics taught, including the foundations of CCE, should be constructed as a continuation from basic education to upper secondary education. In basic education, climate change is addressed from the perspective of building a sustainable future by looking at one's own activities [14] (p. 242). In upper secondary education, CC is part of the transversal competence themes, and it is mentioned in both the common goals and guidelines for upper secondary education and in connection to the specific subject aims and objectives $[15,16,27]$. CC is brought up in shared values of education: "Students understand the importance of their own activities and global responsibility... in mitigating climate change..." [16] (p. 17). It is also mentioned in connection to the topic "Sustainable Lifestyle and Global Responsibility", where "the student knows the factors influencing climate change and they are aware of the significance for the environment and human activities" [16] (pp. 60-64). For individual subjects, $\mathrm{CC}$ has been mentioned in the main contents of biological "Ecology and Environment" studies, which states the ecological effects of CC [15] (p. 142), and geographical "World in Change" studies, according to which the lessons dealt with CC [15] (p. 148) already in the previous curricula, published in 2015. Before that, CC was already mentioned in the geography contents in the upper secondary curriculum published in 2003 [75]. In the most recent curriculum document [16], CC is connected to an increased number of subjects (multidisciplinary), such as language studies, natural science subjects, philosophy, and ethics.

For teachers, two models are designed to facilitate the planning of CC-related teaching: the so-called bicycle model [71] and the problem-centered process model [65]. The bicycle model outlines CC in all its dimensions and as a whole, but in order to function and stay in motion, the CC "bicycle" must actively incorporate every component and requires an active user. In this model, the essential aspects of CCE are described in a simple but comprehensive way: knowledge and thinking skills (wheels); identity, values, and worldviews (frame); action to curb CC (chains and pedals), motivation and participation (saddle); operational barriers (brakes); hope and other emotions (lamp light); and future orientation (handlebars). The problem-centered process model concerning CC, introduced by Ratinen et al. [65], supports teachers in outlining the wide multidimensionality and comprehensiveness of CCE, which in turn facilitates the integration of different aspects of CC into education [10]. In these models, knowledge and thinking skills form the basis for 
CCE. The bicycle model especially [71] pays attention to other educational views, such as values, motivation, identity, emotions, actions, anticipatory hope, and worldviews.

\section{Study Design and Methods}

\subsection{Participants and Settings}

In total, 57 university students from 4 faculties of a Finnish university attended a "Climate change education and sustainable development course" (3 ECTS units) in October 2019. The course dealt with CCE as part of sustainability and global education. The aims of the course were to support university students in recognizing the importance of CCE in schools, becoming aware of the different aspects of CC and its socio-scientific nature, and learning the multidimensional content information related to CC. The course also sought to develop university students' thinking skills related to CC and CCE. Of the course participants, 48 university students (later "respondents") volunteered for the survey and completed the questionnaire at the beginning of the course. The majority of the respondents were studying to become teachers or were at least considering a career as a teacher. The Finnish national curriculum for basic education [14] and upper secondary education [15] — but not textbooks—-were used to design the questionnaire. Most of the respondents had studied the curricula during their pedagogical study year, which is a compulsory module of the subject teacher degree program. Textbooks and other teaching materials vary from teacher to teacher and from school to school, as in Finland, teachers and schools are free to choose teaching materials from different publishers or create and use their own teaching materials.

The gender distribution of the respondents was uneven (female 41, male 7). The age range varied from 19 to 49 years old, with nearly half (44\%) being 19-23 years old and $81 \%$ being under 28 years old. Most of the respondents were first-to-fourth-year university students and represented eight major subjects. The largest groups were university students in educational sciences and geography (Figure 1). Most respondents $(80 \%)$ had completed or planned to earn a teacher's degree for either subject teaching or primary school teaching.

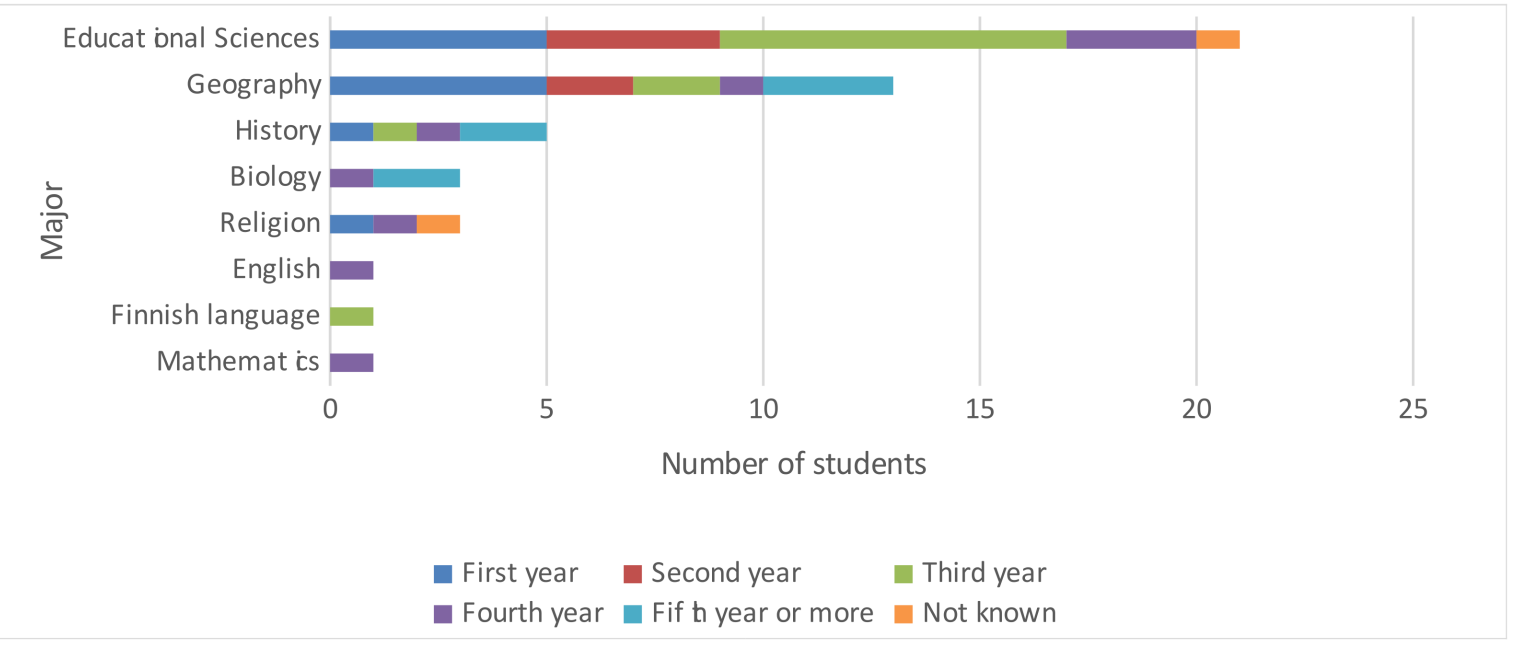

Figure 1. Distribution of respondents $(n=48)$ by their majors and study years.

The most common reason for participating in the course was interest in the course topics. The respondents expressed interest in environmental and climate issues and how they were addressed at different levels of education and in organizations and work communities. Developing one's own competence related to the topics covered in the course from the perspective of future work was mentioned almost as often as a reason for participation in the course. CC issues were also considered to be important and topical. 


\subsection{Measures}

The research questionnaire was designed by using the CCE bicycle model as a foundation [71]. At the beginning of the questionnaire, the aims and background of the study were presented to the respondents. It was emphasized to the respondents that the research focus was on their views rather than on the specific content of the subject. The questionnaire was prepared using the Webropol Survey tool (version 3.0). It consisted of four sections, which included both open-ended and closed-ended questions assessed on a nine-point Likert scale or multiple-choice tasks (Table 1). The first part included questions related to the respondents' backgrounds and their motives for participating in the course. In the second section, the respondents were asked to explain their views about the current state of CC-related upper secondary education. The third section addressed respondents' views and expectations about the future of upper secondary education related to CC. Finally, the last section focused on the respondents' own abilities to act as climate educators. The CCE bicycle model [71] formed the framework of the research questionnaire. The model was introduced to the university students in the first lecture before they answered the survey questions so that the topic was not completely unfamiliar.

Table 1. Structure of the questionnaire and question topics. Open-ended questions eliciting the qualitative data are marked in the table.

\begin{tabular}{l} 
Part \\
\hline I Background \\
(questions, 1-7)
\end{tabular}

II Views on the current state of upper secondary education related to climate change (questions, 8-13)

\section{Topics of Questions}

- Gender, age, major, degree, year of study

- Motivation to participate the course (open-ended)

- What aspects of CC are currently addressed? (eight choices based on the bicycle model in one closed-ended question followed by an open-ended question for reasons)

- Are all aspects covered comprehensively?

- How much is CC dealt with in different school subjects?

- How much climate issues are addressed in other school activities (such as theme events and excursions)?

- What competences upper secondary education develops to follow a climate-friendly lifestyle? (open-ended)

- What kind of competences should upper secondary education provide in the future in relation to CC? (eight choices based on the bicycle model in one closed-ended question followed by an open-ended question for reasons)

- How should teaching about CC be developed? (open-ended)

- Evaluate your own skills as climate educator in relation to different aspects of CCE. (eight choices based on the bicycle model in one closed-ended question)

IV Self-evaluation-ability to act as a climate educator (questions, 17-20)
- Which of the aspects you find most difficult to teach? (open-ended)

- What factors can make it difficult to teach about CC? (open-ended)

- What factors can make it difficult to learn about CC? (open-ended)

\subsection{Analyses}

A mixed-method approach was employed as the research methodology. The qualitative data from seven open-ended questions were analyzed using both inductive and theory-based content analysis [76] (Table 2). NVivo qualitative data analysis software (version 12) was used for organizing, coding, and classifying the qualitative data. 
Table 2. Logics of thematic content classification of qualitative survey data by question topics.

\begin{tabular}{|c|c|}
\hline Question topic & Content classification \\
\hline \multicolumn{2}{|l|}{ Part I-Background } \\
\hline Motivation to attend the course (question 7) & $\begin{array}{l}\text { Inductive content classification } \rightarrow \text { identifying repeated and individual } \\
\text { reasons and classifying them }\end{array}$ \\
\hline \multicolumn{2}{|l|}{ Part II-Current state of CCE } \\
\hline $\begin{array}{l}\text { Aspects of CCE addressed in upper secondary } \\
\text { education (question 9; reasons for question 8) }\end{array}$ & $\begin{array}{l}\text { Inductive content classification } \rightarrow \text { identifying repeated and individual } \\
\text { aspects and classifying them }\end{array}$ \\
\hline $\begin{array}{l}\text { Current competences students gain to follow } \\
\text { climate-friendly lifestyle (question 13) }\end{array}$ & $\begin{array}{l}\text { Grading answers: very good, good, fair, poor, very poor competences. } \\
\text { Inductive content classification } \rightarrow \text { identifying thematic categories related } \\
\text { to the suggested competences }\end{array}$ \\
\hline \multicolumn{2}{|l|}{ Part III-Future CCE } \\
\hline & $\begin{array}{l}\text { Inductive content classification in two phases } \rightarrow \text { First: development } \\
\text { ideas were classified in two major categories: }\end{array}$ \\
\hline \multirow[t]{2}{*}{$\begin{array}{l}\text { Competences that should be developed in the future } \\
\text { CCE (question 15; reasons for question 14) }\end{array}$} & $\begin{array}{l}\text { - developing teaching practices } \\
\text { - } \quad \text { increasing concrete actions }\end{array}$ \\
\hline & $\begin{array}{l}\text { Second: more detailed thematic classification of the ideas within } \\
\text { these categories }\end{array}$ \\
\hline \multicolumn{2}{|l|}{ Part IV-Self-evaluation } \\
\hline \multirow{3}{*}{$\begin{array}{l}\text { Most difficult themes of CCE to teach (question 18; } \\
\text { continuation to question } 17 \text { ) }\end{array}$} & Classification in two phases: \\
\hline & $\begin{array}{l}\text { First: theory-driven classification according to the aspects of the } \\
\text { bicycle model }\end{array}$ \\
\hline & $\begin{array}{l}\text { Second: inductive content classification of the specific challenges stated } \\
\text { in the answers }\end{array}$ \\
\hline $\begin{array}{l}\text { Factors that cause difficulties to teach about CC } \\
\text { (question 19) }\end{array}$ & $\begin{array}{l}\text { Inductive content classification } \rightarrow \text { identifying repeated and individual } \\
\text { factors and classifying them }\end{array}$ \\
\hline Factors that cause difficulties to learn CC (question 20) & $\begin{array}{l}\text { Inductive content classification } \rightarrow \text { identifying repeated and individual } \\
\text { factors and classifying them }\end{array}$ \\
\hline
\end{tabular}

\subsection{Judging the Methodology}

Respecting and ensuring the anonymity of the respondents was important so that their views were not exposed [77]. Therefore, the respondents and their answers were grouped into larger categories such that individual views were rendered unidentifiable.

Qualitative content analysis related to views also includes the potential risk of misinterpreting answers, as well as the inherent subjectivity of classification [78]. Therefore, one of the researchers in our team who did not participate in the original analysis process re-evaluated the categories created during the qualitative content analysis. In this validation process, the categories of the classification with the most observations from the data were reviewed. Two important findings were generated: (1) in the theory-based or deductive classification, the review results were identical to the original classifications, and (2) the subjective element was more noticeable in the inductive content analysis. After this re-evaluation, the team discussed the following observations.

In the theory-based content classification, the categories from the bicycle model [71] were used to classify the responses. The same categories were used in the closed-ended questions preceding the open-ended questions, and they were presented to the respondents before they completed the questionnaire. However, the answers showed that some of the categories, especially "thinking skills", were not fully or similarly understood by the respondents. Some other categories, such as "knowledge", "operational barriers", or "motivation and participation", seemed more unambiguous. This was acknowledged in the results.

The subjectivity of the inductive content classification was seen, for example, in the subcategories related to question 16, for which the respondents gave development suggestions for future CCE. The classification of the answers into two main categories, "developing teaching practices" and "increasing concrete action", was rather straightforward, but in the sub-categories for developing teaching practices, the major classes retrieved from the 
answers-interdisciplinary approach and diversification-were commonly intertwined, and their separation in the answers was difficult. Therefore, in the results, these subcategories were not treated separately. Based on the re-evaluation process, the team reached a final consensus concerning the classification.

Researcher triangulation was an essential part of our analysis process. Our research group consisted of a recently qualified geography and biology schoolteacher, one expert from geography, and two experts from biology and geography education, environmental education, and sustainability education. The latter two for our research team are also experts in educational sciences and experienced teacher educators and researchers.

\title{
4. Results
}

\subsection{Respondents' Views on the Current State of Upper Secondary School Climate Change} Education (CCE) in Finland

For question 8 on the current state of CCE in upper secondary school, the respondents were asked to choose the first, second, and third most common aspects out of eight given choices (Figure 2). More than half of the respondents $(28 / 48)$ chose "increasing and structuring knowledge" as the most common aspect of upper secondary CCE, and nearly all $(43 / 48)$ included it as one of the three most common aspects. "Developing thinking skills" (31/48) was chosen as the second most common aspect, and "encouraging action" $(19 / 48)$ was chosen third. The third choice concerning aspects in CCE (green bars) was rather evenly distributed into all eight categories.

\author{
increasing and structuring knowledge \\ developing thinking skills \\ encouraging action \\ future orientation \\ identity, values and worldview \\ increasing motivation and participation \\ operational barriers \\ rising hope and emotions
}

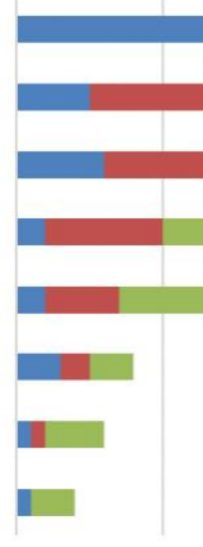

$0 \quad 10$

Number of mentions

\section{airst $\quad$ second $\quad$ third common}

Figure 2. The respondents' $(n=48)$ views on the first, second, and third most common aspects of upper secondary school climate change education (CCE).

Half of the respondents justified their views of the current state of CCE (question 9) by referring to their own experiences in upper secondary school or to those of friends in their inner circle. One-third of the respondents justified their views on the basis of their conceptions, assumptions, and beliefs, the actual origins of which, however, were not specified in more detail. In some of the answers, justifications were based on causeand-effect relationships (see the answer below). Three respondents justified their choices by referring to social debate, the media, or the upper secondary school curriculum. Four respondents did not give any reason for their choices.

One respondent in the 29-33 age group answered as follows: “... their [teachers'] knowledge may also be very limited. In this case, the teaching is more likely to focus on cognitive 
teaching... Through this, students are most likely encouraged to think... and think about subjects from different perspectives... Thirdly, I believe that in teaching there appear barriers concerning acting, while these barriers appear in the lives of many citizens. This makes awareness of these things very visible".

Individual answers were also justified by knowledge and skills learned during one's own university studies, from general social debate and media and also from curricula. In a few answers, the respondents did not substantiate their views at all, or they stated that they had no views related to the topic. Additionally, a few respondents misunderstood the question.

The choices respondents selected for question (10) (How comprehensively is climate change addressed in upper secondary education?) varied. The majority of the respondents $(27 / 48)$ felt that CC was addressed in an excessively one-sided manner in current upper secondary education. In this context, the term "one-sided" can be understood to refer to the possibility that teachers only use information in the text or avoid adding information that may be controversial or depressing. This does not mean that the respondents believe that the benefits of climate change should be taught. The second most common view (14/48) was that too little was being done about CC. No one felt that CC was being addressed too much in upper secondary education, but according to some respondents, climate issues were being addressed appropriately $(7 / 48)$.

The results also revealed that the respondents perceived aspects related to $\mathrm{CC}$ to be most prominent in geography, biology, and ethics and at least present as often in mathematics, guidance counseling, physical education, and music. Topics related to CC were also dealt with in multidisciplinary learning events, theme days, and class trips (69\% of answers were between 4 and 7 on the 9-point Likert scale).

Many respondents (36\%) also felt that current CCE in upper secondary schools provides poor or rather poor preparedness to following a climate-friendly lifestyle (question 13). Lack of capability was perceived to be due to shortcomings in teaching practices and onesided treatment of the issue. On the other hand, the importance of the student's interest and motivation was particularly emphasized. One-fifth of the respondents felt that CCE provided a sufficient basis for learning and support for a climate-friendly lifestyle, as long as the students themselves were willing to develop the required skills. Some respondents also had the opinion that the development of skills is often entirely the responsibility of the student because the handling of climate issues in upper secondary education is too limited. In addition, the courses selected by the student were reported to play an important role in developing the skills of CCE.

The eight respondents who had the opinion that teaching supports a climate-friendly lifestyle well or rather well clarified that it includes knowledge of CC, climate-friendly action, and the ability to themselves act in a responsible way and acquire information retrieval skills. They also thought that upper secondary CC teaching promotes thinking skills such as critical thinking and motivates them to act in a way that is sustainable in terms of CC. They also wrote that teaching should clarify more precisely and unambiguously what is meant by "climate-friendly" and how the students themselves could act responsibly in terms of CC. They also wanted to learn concrete approaches to teaching. The respondents emphasized increasing and diversifying teaching and developing the treatment of emotions related to $C C$, such as climate anxiety. In addition, one respondent considered it important for the entire school community to be exemplary in the development of the school's climatefriendly activities, as well as increasing future thinking:

'... more "thinking about the future", e.g., what kinds of companies will there be in the future, what kinds of business ideas will become more common and be successful in the future, e.g., sharing and lending culture, rental of services, etc.' (Respondent 17, age group: 24-28) 


\subsection{Respondents' Views of Future Upper Secondary Education Related to Climate Change (CC)}

The respondents thought that upper secondary education related to CC should focus primarily on increasing and structuring knowledge, developing thinking skills, and increasing motivation and participation in CC activities in the future (Figure 3). The least emphasis was placed on inspiring hope and other positive emotions, as well as on awareness of operational barriers. Indeed, the respondents often stated that prioritizing aspects of CCE was not easy because all of them were perceived to be important.

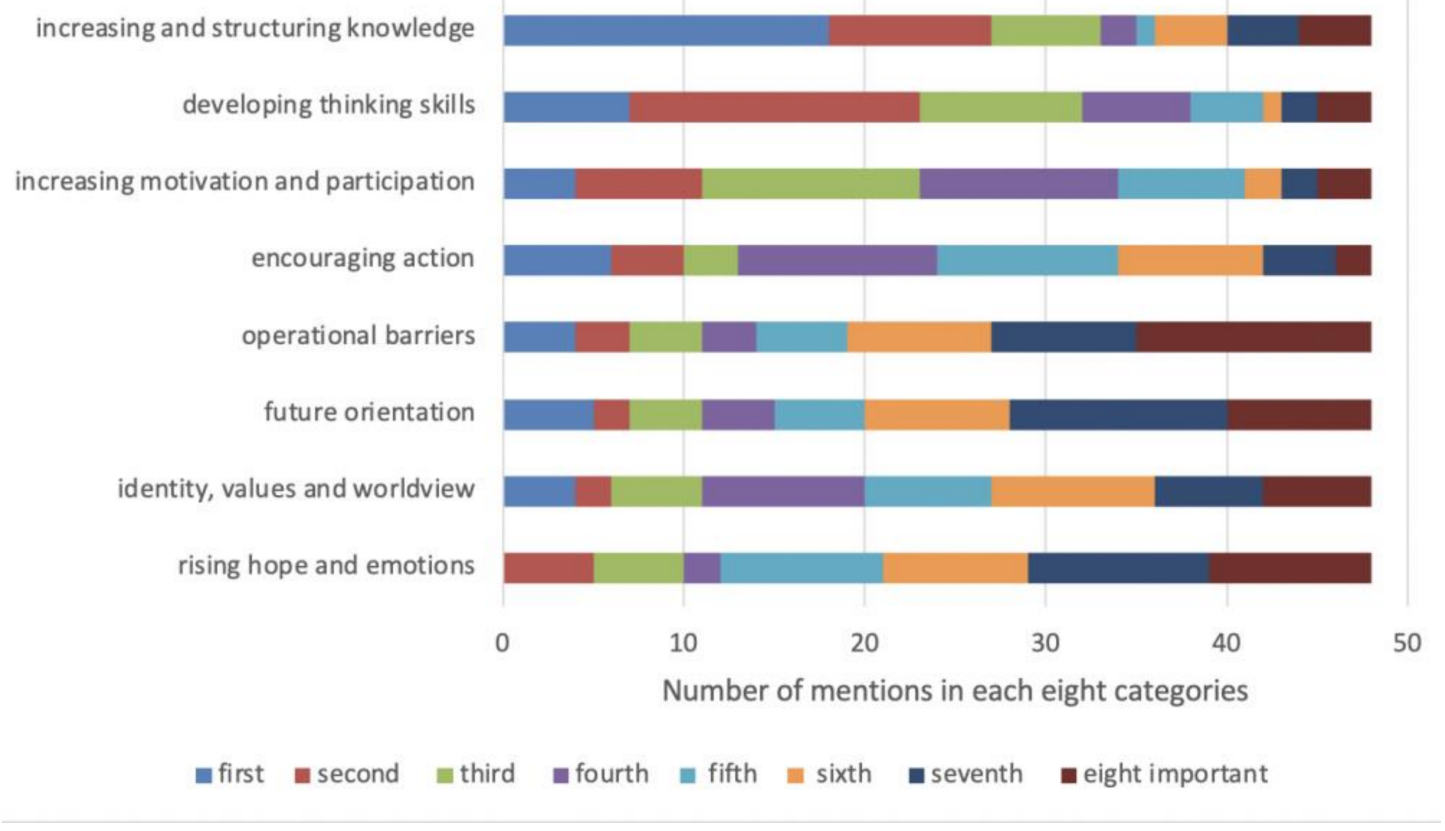

Figure 3. Aspects of CCE in future education prioritized by the respondents $(n=48)$ from the first to the eighth most important.

The respondents shared the idea that future upper secondary education related to CC should be developed by focusing on both developing teaching practices and increasing concrete actions. The development of teaching practices referred primarily to the increase and diversification of teaching, which meant that climate issues should be addressed more widely in teaching. The respondents also emphasized the importance of increasing diversity, but they did not explain more deeply what they meant with diversity. In general, diversity can include many aspects, from a multidisciplinary approach to teaching and learning practices, as well as the practices of the school as a community. According to the respondents, CC is already discussed quite widely in certain subjects, such as geography and biology, but including climate issues in interdisciplinary cooperation and in the teaching of most if not all subjects was considered essential.

"Teaching should be multidisciplinary: taking place both in social sciences and in visual art studies". (Respondent 42, age group: 19-23 years)

"More systematic, through integrating subjects, not focusing on studies of geography and biology only". (Respondent 29, age group: 29-33 years)

According to the respondents, education should also be developed by improving the handling of emotions related to CC. This in particular means an effort to reduce climate anxiety among upper secondary school students and increasing hope for the future. It was also considered important to deal with climate issues in a compulsory upper secondary school course so that the students' course choices would not have as important a role in the development of CC-related skills. In addition, the respondents proposed future thinking skills in teaching, monitoring the development of students' climate skills during upper secondary studies, and providing additional training related to $\mathrm{CC}$ for teachers: 
"Focusing on climate issues at the political level, e.g., in social sciences. Knowledge of, for example, barriers to applying flight taxes can tutor you for studies in the university". (Respondent 14, age group: 24-28 years)

"Group discussions and sharing your own experiences. The teacher can make use of your comments and thoughts, adding them in their teaching". (Respondent 28, age group: 19-23 years)

"You tell ... more about, e.g., vegetarian food and proteins of vegan origin ... You share ... in your health education classes ... vegetarian food recipes easy and fast to make". (Respondent 25, age group: 19-23 years)

In their answers concerning future upper secondary education related to $\mathrm{CC}$, the respondents underlined the importance of supporting students' participation in CC activities and the need for concrete instructions for action. It was found to be important to support students in taking positive CC-related actions and help them improve their influential skills. One respondent suggested that climate tax added to the flight ticket price is a respondent's concrete instruction of action. This may reflect how widely the university students see the climate issues and how much they value the knowledge of different means to combat CC.

More concrete examples of desires related to everyday life and distinctive directions for CC actions were also listed by the respondents. These included the means to better realize what a climate-friendly lifestyle means and how students could follow its guidelines. The respondents also valued increasing multidimensional teaching based on action, referring to, for example, organizing workshops, theme days, and thematic courses related to CC:

"... more practical advice to the students on how they themselves can influence... you need to remind them that small deeds matter...". (Respondent 10, age group: 19-23 years)

"It would be fine, if ... you could offer knowledge ... concretely through various projects. You should... really put effort into these ones and they should be made long-lasting vehicles modifying/changing one's thinking". (Respondent 8, age group: 19-23 years)

The school community as a whole and its actions were mentioned as an example of climate-friendly activity, referring to demands that goals for sustainable climate education should be visible in daily school practices (e.g., recycling and reducing food waste). The respondents felt that they themselves, as upper secondary school students, expected to be offered CCE and that issues related to CC should be included in daily activities at school, instead of just on special theme days only.

\subsection{Respondents' Views of Their Own Capacity to Address Climate Change (CC) Issues}

According to the respondents' views, they considered their own ability to deal with different aspects of CCE to be relatively good (Figure 4). They identified developing thinking skills and encouraging CC action as the strongest of their abilities. The ability to inspire hope and other positive emotions, as well as future orientation, were considered their weakest abilities.

The respondents were also asked which of the aspects in CCE were difficult to manage and why. The results revealed that the most difficult aspect of CCE to implement in teaching was dealing with identity, values, and worldviews. The choice was justified, for example, by the fact that, due to different backgrounds and values, it can be difficult for both teachers and students to face and deal with views that differ from their own. Some respondents did not even know what it meant to take identity, values, and worldviews into account in teaching insufficient time and other resources (often financial). The inability to remain value-neutral and one's own lack of expertise were also identified as challenges. 


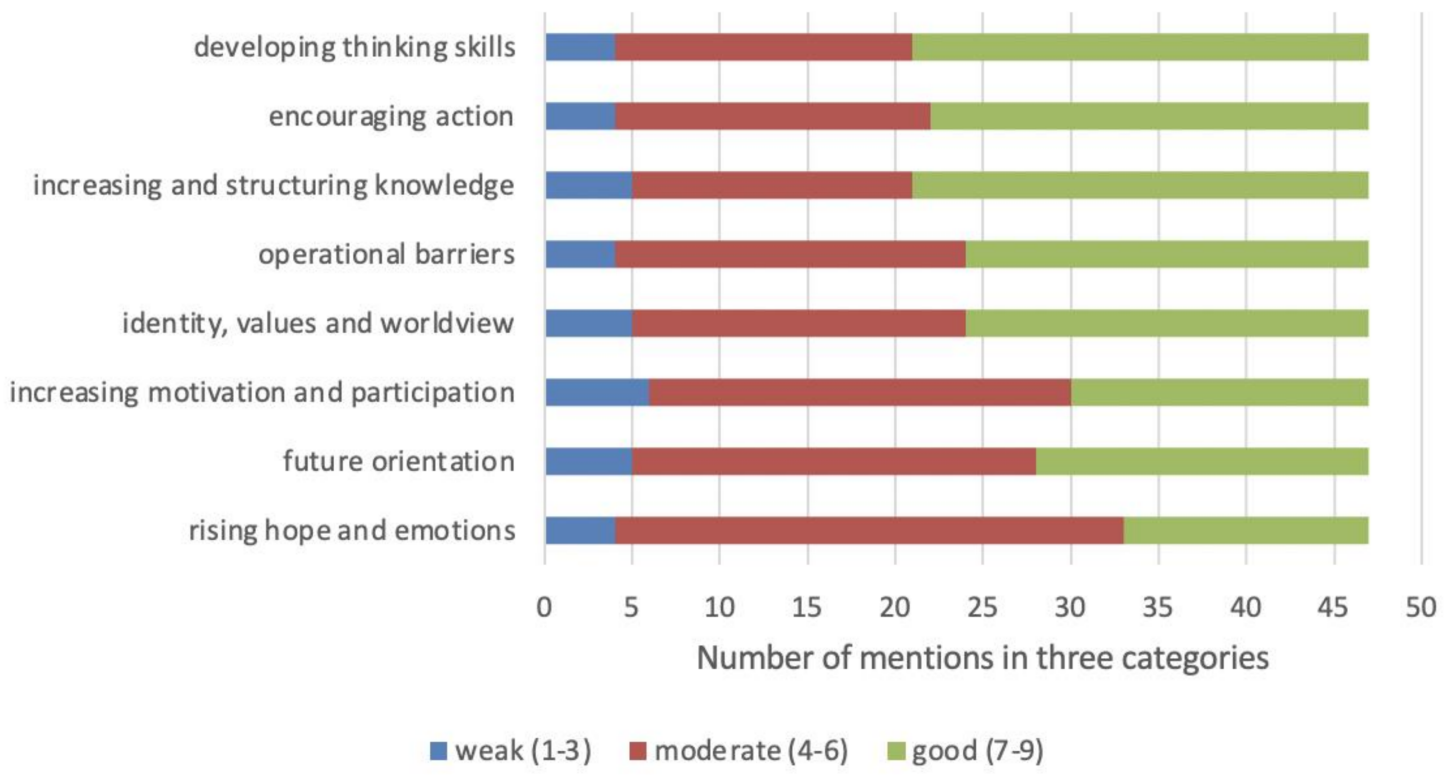

Figure 4. Respondents' $(n=47)$ views of their own abilities to manage various aspects of CCE.

According to the respondents' views, increasing motivation and participation was also among the issues that were difficult to manage due to their own lack of knowledge on CC issues. Various individual factors influencing the emergence of motivation as well as the lack of sufficiently diverse means of motivation were considered challenging. One respondent (Respondent 31, age group: 19-23 years) wrote "Motivation and increasing participation is demanding while I haven't received any pedagogical tips", while another (Respondent 48, age group: 19-23 years) remarked "increasing motivation so that it doesn't end in a couple of months". However, motivating and involving students, particularly those who have negative attitudes toward CC, was considered difficult.

Dealing with emotions about CC, both their own and those of secondary school students, was considered challenging. Respondent 35 (age group: 34-38 years) wrote "Students certainly have a wide range of beliefs and reconciling them with the right knowledge can provoke emotional discussions". To remain optimistic was found to be difficult, especially amidst the abundance of depressing CC news, which made the idea of encouraging students and preventing hopelessness challenging. Some respondents felt that assuming the role of addressing emotions was unfamiliar and uncharacteristic of them.

Increasing and structuring knowledge and supporting future orientation were chosen as the least challenging aspects of CCE. However, it was considered difficult to increase and structure the constantly growing amount of knowledge and keep it up to date. Maintaining one's own optimism was reported to be difficult by a few respondents when teaching future orientation.

Factors involved in hindering the teaching of CC were also a focus in this study. With three questions, more detailed information was gained about what, in practice, the respondents viewed as difficulties and whether they were more related to learning or teaching. The respondents thought that the biggest challenges to teaching issues related to CC were connected to the students' negative opinions and beliefs about CC obtained from their inner circle, such as family and friends, as well as from the media and discussions on social media (question 19). "Everything that happens in the free time of children and young people, the opinions and actions of parents and other close people. If a young person's initial attitude has developed into a negative one, it is difficult to teach him or her things related to it" (Respondent 3 , age group 19-23 years). Among these negative opinions were aggression, indifference, desire for comfort, laziness, and lack of interest or motivation. The teaching of aspects of CC was also hampered by factors related to the quantity and quality of information available, such as the problems caused by the ever-increasing amount of information. One 
respondent (Respondent 8, age group: 19-23 years) stated "The information is constantly changing and sometimes even in conflict with each other". The large amount of erroneous and misleading information on social and traditional media was also considered problematic for constructing knowledge based on scientific information. The importance of source criticism was also emphasized in the responses.

The adequacy of available time and other resources, as well as climate anxiety, were also considered challenges for teaching about CC. One's own despondency was especially found to have a debilitating effect on the teaching of CC issues. However, dealing with such emotions was nonetheless considered important. One's own inadequate skills and a sense of inadequacy in addressing CC were also viewed as an obstacle to teaching. Feelings of inadequacy in this context referred to the experience that one's own actions as both a teacher and an ordinary citizen did not matter. Ineffective political decision making concerning the identification and implementation of suitable teaching methods, the lack of effective methods for combating CC (due to increasing desperation among both students and teachers), an overemphasis on CC, and ambiguity in relation to the responsibilities of different disciplines in teaching CC in upper secondary schools were noted to be problematic.

Based on the respondents' answers, learning about aspects related to CC was also hampered by a lack of motivation among students and their resulting reluctance to address climate issues. Climate anxiety and other negative feelings about CC, as well as factors affecting the amount and quality of available information, were also specified as exacerbating learning challenges. The respondents felt that incorrect and even intentionally false information made learning difficult, as it can be challenging for students to distinguish between correct and incorrect information. In addition, the already large and ever-increasing amount of information related to CC can confuse and frustrate students as, on the whole, it is difficult to manage due to the multiple and often contradictory messages such information contains.

The scale and complexity of CC were also perceived as making it difficult to learn about CC issues. Among other factors, the lack of concrete information, the fragmentation of information, and the global nature of the effects of $\mathrm{CC}$ were found to make it a difficult phenomenon to understand, one which can be challenging for many students. One respondent (Respondent 33, age group: 24-28 years) expressed this in the following way: "The confusion of terms, the diversity and abstractness of definitions and models, the lack of concreteness, the difficulty of perceiving the size classes of phenomena, the fact that one does not immediately see the result of one's own activities". Another respondent (Respondent 6, age group: 19-23 years) wrote "distance, people are talking about big global effects that may not be visible in our immediate lives".

The respondents also mentioned barriers to learning and challenges related to learning, such as various learning difficulties and students' own weak and atomistic knowledge base. In addition, inadequate or uninteresting teaching and a lack of time and other resources (including financial resources) were perceived as problematic.

\section{Discussion}

One aim of this study was to examine the respondents' views of the current state of CCE. According to the respondents' views, current upper secondary education related to $\mathrm{CC}$ focuses mainly on increasing and structuring knowledge and developing thinking skills. The other aspects of CCE, such as identity, values and worldviews, increasing motivation and inclusion, encouraging action, introducing future orientation, operational barriers, and inspiring hope and positive feelings were not felt to be largely present in the current upper secondary CCE. These results are in accordance with the priorities of the Finnish national core curricula for upper secondary school $[15,16]$.

Based on the respondents' views, topics related to CC are addressed in upper secondary education in a way that is not only one-sided but also inadequate. In Finland, teaching is largely based on scientific facts presented in textbooks [79] (Kärnä, Hakonen, 
and Kuusela, 2012). As a result, the treatment of the economic and social aspects of CC especially may be limited. This result corresponds with the findings of Lehtonen and Cantell [9] and Tolppanen et al. [11], who demonstrated that the treatment of CC at all levels of education is still too partial and incomplete. CC is often perceived as a theme that belongs mainly to the natural sciences $[9,11]$. This makes it difficult to implement multidisciplinarity and emphasize responsibility among individual teachers, although research has shown that community action can make a significant contribution to achieving CCE goals [42,80].

The outcome of the absence of CC instruction in, for example, guidance counseling and psychology can be considered surprising in terms of the learning objectives mentioned in the upper secondary school curriculum [15]. In guidance counseling, the presentation of various education and career options and the analysis of future prospects are crucial tasks, and the impact of CC on these options and prospects is undeniable. Envisioning the future is important primarily in terms of future planning but also with respect to the development of opportunities for influencing CC issues [81]. Maintaining mental well-being by identifying and mitigating psychological issues based on, for example, the effect of CC-related negative emotions can be considered natural [15]. Climate anxiety and other negative emotions among teachers and learners, as well as the attitudes arising from them, were found to make it difficult to address issues related to CC in both our study and others $[26,49,62,64]$. Special expertise in the subject of psychology would therefore be particularly useful in dealing with and providing proper instruction about negative emotions related to CC.

Upper secondary school education of CC was perceived to provide either a weak or relatively weak capacity to follow a climate-friendly lifestyle. The respondents mentioned that the lack of capability concerning a climate-friendly lifestyle was perceived to be due to shortcomings in teaching practices and one-sided treatment of the issue. The one-sided treatment can be interpreted in the context of the curricula and teaching. Curricula in Finland form the framework for teaching, but Finnish teachers have the right to decide for themselves what and what kind of information is covered in the lessons. When choosing information, the teacher can consciously or unconsciously emphasize things according to his or her own views [82] (Pihkala, 2017). This may lead to little discussion of the severity of CC in the lives of young people [83] (Särkelä, 2021) and how their own choices and lifestyles can make an impact. The research literature has also shown that learners' competence related to CC often remains at a rather low level and contains numerous misconceptions $[10,52,53,64]$. Students' motivation and attitudes as well as the courses they choose were also believed to affect their level of readiness to act. Previous studies support this finding, as they suggest that negative attitudes among students make it difficult to address issues related to $C C$ in teaching $[26,62]$.

This survey was also aimed at assessing the views of respondents regarding the need to develop CCE in upper secondary school in the future. According to the results, it is important to focus primarily on increasing and structuring knowledge and developing thinking skills related to CC in upper secondary education in the future, as is the case today. These findings are in line with those of previous studies [10,11,26]. However, teaching that focuses solely on increasing and structuring knowledge and developing thinking skills is insufficient for cultivating the skills needed for a climate-friendly lifestyle, and for this, more holistic CCE is needed [11,52-54]. This issue was also reflected in the respondents responses, as they expressed how difficult it was to prioritize CC aspects, all of which were considered essential.

The respondents' views of current and future CCE differed most clearly in terms of motivation and inclusion. In their views, these factors were not currently evident in teaching but should be. The research literature also emphasizes the importance of promoting inclusion and empowerment from the perspective of adopting a more sustainable and climate-friendly lifestyle [11,52-54]. The Finnish National Climate Responsibility Education 
Program [16] also aims to increase and enhance the participation and empowerment of students to perform active citizenship.

In order to improve the capacity for a climate-friendly lifestyle, future education related to CC should, based on the respondents' views, focus on increasing and diversifying teaching and strengthening the role of multidisciplinarity. Similar observations have also been made in the research literature, which states that current CCE is still too weak in terms of quantity and quality $[9,11]$. The importance of multidisciplinarity has also been highlighted in studies, according to which a comprehensive understanding of CC requires cooperation between different disciplines and school subjects [84].

According to the respondents, in the future, more focus should be placed on increasing the tangible, functional, and inclusive elements of CCE. This means, among other things, investing in the motivation and involvement of upper secondary students and providing concrete examples of climate-friendly choices and their importance in combating CC. The importance of encouraging climate-friendly activities and the concreteness of teaching has also been observed in the research literature [9]. However, the lack of teaching methods that are considered effective has been found to make it difficult to add functionality to teaching [41]. The respondents also felt that it was important for the goals of CCE to be reflected in the everyday activities of the entire school community. The importance of community, and especially the example of community leadership, has also been underscored in the scientific literature $[8,42,80]$.

The respondents' ability to teach and learn with topics related to $C C$ was also a subject of this study. The respondents shared the idea that current upper secondary education offered rather poor instruction concerning how to follow a climate-friendly lifestyle. As such, one would expect that they would have also rated their own readiness to deal with $\mathrm{CC}$ issues to be poor. However, the respondents considered their current skills in dealing with different aspects of CCE to be relatively good. They felt confident in their capacity to support students' thinking skills and actions, whereas they noted their ability to inspire hope and promote other positive feelings, as well as continue cultivating them in the future, to be comparatively weak. In the scientific literature, teachers' and students' self-efficacy (i.e., one's belief in their power to overcome the challenges of their own work) was found to improve their proficiency as climate educators $[59,85]$. Among other factors, teachers with stronger self-esteem were found to incorporate CC issues more boldly and persistently in their own teaching. Thus, during pedagogical studies, it is already important to strive to develop respondents' self-esteem, the first step of which is to identify their own abilities. There were some inconsistencies in the respondents' views, as they assessed their readiness to deal with aspects of CCE in a different way than when asked to define and justify the areas they considered to be most difficult. These inconsistencies may be due to the uncertainty in one's own views. This is likely because respondents' views of their own ability to address CC issues are not entirely unambiguous to themselves.

The respondents found it challenging to inspire hope and other positive feelings, as both their own and the students' negative feelings about CC were considered difficult to manage. However, in the research literature, the expression, encounter, and processing of emotions were all found to play a significant role in CCE $[9,11]$. In a study by Lombardi and Sinatra [60], for instance, it was revealed that the teachers' own unaddressed negative emotions and attitudes, such as hopelessness, can also influence the ways in which they teach CC issues. For example, teachers may inadvertently manipulate students by transferring their own feelings to them, which has been found to affect students' attitudes and motivation $[11,26]$. The development of the emotional skills of teachers and students can therefore be said to be important.

The consideration of identities, values, and worldviews was also perceived to be a challenging dimension of CCE. The different views, attitudes, and opinions of both teachers and students concerning $\mathrm{CC}$, as well as the contradictions and conflicts caused by them, were considered difficulties in teaching and learning about CC. According to the research literature, teachers often find that addressing controversial issues such as CC 
can evoke strong opinions and feelings that are alien, unpleasant, and even frightening to them, which naturally makes it difficult to continue to pursue these issues $[60,61,63]$. In the current study, the respondents found it challenging to assume a suitable role as a climate educator. Feelings of insecurity can manifest, for example, as a one-sided treatment of a topic (i.e., a repetition of the facts contained in a textbook or, at worst, avoidance of the topic) [86] (cf. Wolff, 2011), because teachers often do not emphasize things and topics they are not sure about. Raath and Hay [85], for instance, emphasized the importance of supporting teachers and student teachers in outlining their own roles as builders of a more sustainable and climate-friendly future. It is therefore essential to develop teachers' abilities and courage to address CC issues in their teaching by, for example, developing self-efficacy.

In the research literature, the lack, fragmentation, and narrowness of teachers' information concerning CC, as well as various misconceptions, have often been cited as a factor hindering the teaching of climate issues $[10-12,52,53,60,61]$. The respondents considered their own ability to add and structure information to be quite good, with only a few exceptions. These respondents mentioned that teaching CC is problematic for them because their knowledge of CC is deficient. The respondents who demonstrated interest in this topic were familiar with adding and structuring information, which is why this area was often mentioned as the easiest area of CCE.

The respondents shared the most conflicting views about the challenge of future guidance. They felt that their readiness to deal with this aspect was the second-weakest, but they nevertheless identified future guidance as the second-easiest of the aspects of CCE. It is difficult to unambiguously define what such a result could lead to, and as such, this issue should be studied in the future.

The respondents considered preconceived notions and opinions emerging from their inner circles, from the media, and from social debate to be by far the most difficult factor in teaching about CC. Previous studies have shown that learners' attitudes toward CC and negative feelings, such as CC denial, can make it difficult to address CC in teaching $[26,62,64]$. However, many other factors, such as gaps in teachers' knowledge and skills $[52,61]$ and a lack of multidisciplinarity $[9,11]$, have been found to pose more challenges to teaching. It may be that the respondents found it difficult to dispel negative attitudes because of, for example, the extremely negative opinions and views prevalent in traditional and social media. Consequently, such negative opinions and views may have been more familiar to the respondents than comprehensive and neutral perspectives concerning cross-cutting issues.

The continuous proliferation of information and the ongoing controversies concerning the sources of various types of information have been shown to complicate efforts by teachers and students to stay updated, increase distrust of research data related to CC [59,62], and exacerbate climate anxiety and deficient skills. In turn, prevailing social and political values, attitudes, and opinions have generally been found to have a negative impact on the time and economic resources directed at tackling CC, as political interests often conflict with the goals of CCE $[53,61,87]$. Negative feelings related to CC and teachers' lack of competence have already been found to make it more challenging to address climate issues in teaching.

Concerning future research, it was surprising that none of the respondents mentioned diversity or multidisciplinarity as a factor hindering the teaching or learning of CC-related issues. However, in the relevant literature, multidisciplinarity and empiricism have been regarded as presenting challenges to the achievement of CCE goals $[11,60,61]$. Deficiencies and misconceptions related to high school students' skills were also not considered to be problematic, despite the frequency with which they are mentioned in the literature $[10,11,52,53,64]$.

Although factors influencing respondents' views can be highlighted based on the findings of this study, it is not possible to propose an unambiguous explanation for them. The teacher's role as a developer of knowledge related to CC is important, which is why the teacher's views of their own knowledge, skills, values, and attitudes as well as the identification of the factors that influence them are relevant. Deficiencies in teachers' knowledge 
about climate issues [10,61] and negative attitudes toward CC and its treatment [61,62] only serve to underscore how crucial it is to identify their underlying factors. An analysis of the epistemic worldviews that may influence views and their formation, as well as the cognitive factors that underlie their development, can help to dispel, for example, misconceptions about CC among both teachers and students [88].

The majority of the respondents were studying to become teachers or were at least considering a career as a teacher. It was therefore warranted to outline the underlying reasons for their views, as these reasons cannot be assumed to correspond exactly to reality (e.g., due to the age category of respondents, they were mostly young people just having finished their upper secondary school). First, age was found to be one of the factors influencing the formation of perceptions [89]. For example, a study by Bråten et al. [90] found that younger university students' views of CC were more developed than those of older university students because, among other reasons, younger people had studied CC more recently. It was also considered possible that younger people were more willing to present politically correct views of CC.

Epistemic beliefs and educational background have also been found to influence the formation of views, as they are linked to an individual's understanding of the nature of knowledge and knowing [91]. For example, those with a background in social science education have been shown to formulate perceptions in a very different way than those with a focus on natural science subjects. University students from eight different majors participated in our research, and it can be assumed that differences in their epistemic starting points affected their views of CC and related teaching.

An individual's enthusiasm for and interest in as well as familiarity with a topic also play a role in the formation of perceptions $[88,89]$. Since the present study was conducted in connection with an optional CCE course, it can be assumed that the respondents were more interested in the topic than average individuals and were thus not representative of all student teachers. More specifically, they had already developed views on CC and CCE before starting the course, and as such they were already familiar with them. However, strong interest and enthusiasm for a topic can also distort perceptions, as intense feelings of familiarity have often been found to be erroneously mixed with information or even facts $[88,90]$.

The respondents' views may also have been influenced by, for example, their personal experiences, such as their school experiences, which may have strengthened their belief in the correctness of their own perceptions $[88,91,92]$. The cultural and social living environment, political and ideological atmosphere, various media, public debate, and other people's opinions also influence the formation of perceptions by modifying individual values and attitudes $[25,90,91]$. Thus, they may have also influenced the views of the respondents in our research.

The origins of views cannot be unambiguously determined, as they are often based on different imaginations, assumptions, intuitions, or logics. For example, the formation of the respondents' views related to CC and its teaching involved the summation of numerous different individual and community factors, as well as conscious and unconscious processes [92]. Therefore, determining the background factors responsible for views may have been challenging for the respondents themselves. Moreover, as the research questionnaire did not directly ask the respondents to consider the origins of their own views, interpreting these origins would be particularly challenging.

Interestingly, some of the respondents openly admitted that they did not really know much about the current content or teaching methods applied in upper secondary schools concerning CCE. These respondents also responded "I don't know" to many other questions related to CCE. Such honesty indicates that the respondents did not feel pressured to provide a more detailed answer when they did not feel they knew much about the topic, which had the effect of enhancing the reliability of the research results. However, some of the respondents stated that current CCE was simply "good" or "bad" without offering 
more analytical reasons for their answers. Correspondingly, those who did provide more analytical responses did not express their opinions about the quality of teaching.

As some of the respondents were unsure of their views or did not have an opinion on the topic, excluding the option to choose "no answer" in the multiple-choice questions from the questionnaire might have affected the results. According to the literature, there is no consensus about the effects of omitting this option on the reliability or validity of a study [93]. However, choosing the "middle option" is usually more frequent when the "no answer" option is not available [94]. In addition, employing a nine-point Likert scale might have impacted the results if the respondents had difficulty identifying which option corresponded the closest to their views. It has been stated that scales comprising more than seven choices can decrease the reliability of the answers [95], but a higher number of choices can also increase the validity and reliability of a study [96]. In the latter case, however, it is essential that all answer options are carefully named.

\section{Conclusions and Implications}

The research literature related to CCE supported the respondents' views concerning the current and future state of CCE in upper secondary schools. The respondents, who were university students, felt that current upper secondary education had a rather poor capacity to promote a climate-friendly lifestyle. However, they still considered their own capacities to address CC issues to be relatively good. There were also other inconsistencies in the student-specific responses, which may indicate that the respondents' views of their own competence were not very strong. The respondents considered the inclusion of CC issues in upper secondary education to be important and wanted to develop themselves further as CCE educators. The results also indicate that the university students were motivated to increase and develop CCE. However, they were not qualified to teach CCE. Therefore, they should be offered opportunities to develop as CC educators during their studies, as their competence will ultimately and directly affect the knowledge, skills, values, and attitudes of their students and thereby the achievement of CCE goals. Additionally, the climate-friendly lifestyle should be supported not only by teachers but by the entire school community.

There are many factors that influence students' enthusiasm for working on CC. Research on CCE shows that various teaching and learning opportunities increase the understanding of key issues in climate change [95]. Transformative pedagogy with an art-based and participatory methodology can motivate students to act by creating personal meanings through locally significant climate change action projects. It can also add joy and belief in the student's own ability to take concrete steps toward sustainable change (cf. [96]). Additionally, intercultural topics combined with place-based collaborative learning can enhance students' learning and develop their self-esteem [97]. Support of family and the community is a particularly important source of strength and capacity to learn and cope with stressors, including those associated with climate change. In addition, students' leadership in climate action also inspires other students to participate in their communities [5].

Focusing on the university students' views gives a good possibility for teacher educators to try to clear some misunderstandings concerning the upper secondary CCE and consider the variety of students' views as a starting point when planning their teaching. Thus, the respondents' knowledge and skills with regard to CC, as outlined in this study, can be extended to develop teacher training and thereby cultivate skills in CCE. It would be interesting to further explore in depth the views of a broader range of university students about CC and CCE, as only those who were interested in CC or CCE participated in the current study.

Author Contributions: Conceptualization, E.Y.-P., E.J. and S.M.; methodology, E.Y.-P., E.J., S.K. and S.M.; data gathering E.Y.-P. and S.K.; validation, E.Y.-P., E.J., S.K. and S.M.; formal analysis, E.Y.-P., S.K. and S.M. investigation, E.Y.-P., E.J., S.K. and S.M.; data curation, E.Y.-P., E.J. and S.M.; writingoriginal draft preparation, E.Y.-P., E.J., S.K. and S.M.; writing-review and editing, E.Y.-P., E.J. and S.M.; visualization, E.Y.-P. and S.M. All authors have read and agreed to the published version of the manuscript. 
Funding: This reseearch received no external funding.

Informed Consent Statement: Informed consent was obtained from all subjects involved in the study.

Data Availability Statement: The data presented in this study are available on request from the corresponding author. The data are not publicly available due to privacy.

Conflicts of Interest: The authors declare no conflict of interest.

\section{References}

1. IPCC (Intergovernmental Panel on Climate Change). Contribution of working group II to the fifth assessment report of the intergovernmental panel on climate change. In AR5 Climate Change: Impacts, Adaptation, and Vulnerability. 2014. Available online: http://www.ipcc.ch/report/ar5/wg2/ (accessed on 19 April 2021).

2. Flora, J.A.; Saphir, M.; Lappé, M.; Roser-Renouf, C.; Maibach, E.W.; Leiserowitz, A.A. Evaluation of a national high school entertainment education program: The Alliance for Climate Education. Clim. Chang 2014, 127, 419-434. [CrossRef]

3. Myllyniemi, S. (Ed.) Environment. In Nuorisobarometri: Valtion Nuorisoneuvoston Julkaisuja 56; Grano: Helsinki, Finland, 2017.

4. Budziszewska, M.; Głód, Z. "These Are the Very Small Things That Lead Us to That Goal": Youth Climate Strike Organizers Talk about Activism Empowering and Taxing Experiences. Sustainability 2021, 13, 11119. [CrossRef]

5. MacKay, M.; Parlee, B.; Karsgaard, G. Youth Engagement in Climate Change Action: Case Study on Indigenous Youth at COP24. Sustainability 2020, 12, 6299. [CrossRef]

6. Dufty, N. A new approach to disaster education. In Proceedings of the International Emergency Management Society (TIEMS) Annual Conference, Manila, Philippines, 13-16 November 2018; Available online: https://www.academia.edu/37825155/A_ new_approach_to_disaster_education?email_work_card=view-paper (accessed on 19 April 2021).

7. Rinne, R.; Kivirauma, J.; Lehtinen, E. Johdatus Kasvatustieteisiin; PS-kustannus: Jyväskylä, Finland, 2015; ISBN 978-952-451-634-1.

8. Anderson, A. Climate change education for mitigation and adaptation. J. Educ. Sustain. Dev. 2012, 6, 191-206. [CrossRef]

9. Lehtonen, A.; Cantell, H.; Ilmastokasvatus Osaamisen ja Vastuullisen Kansalaisuuden Perustana. Suomen Ilmastopaneelin Raportti, 1. 2015. Available online: https:/ / www.ilmastopaneeli.fi/wp-content/uploads/2018/10/Ilmastokasvatuksen-raportti9.6.2015.pdf (accessed on 19 April 2021).

10. Ratinen, I.; Kinni, A.; Muotka, A.; Sarivaara, E. Kohti Ratkaisukeskeistä Ilmastokasvatusta. Suomen Ilmastopaneelin Raportti. 2019. Available online: https://www.ilmastopaneeli.fi/wp-content/uploads/2019/11/Ilmastokasvatusraportti_final.pdf (accessed on 20 November 2021).

11. Tolppanen, S.; Aarnio-Linnanvuori, E.; Cantell, H.; Lehtonen, A. Pirullisen ongelman äärellä: Kokonaisvaltaisen ilmastokasvatuksen malli. Kasvatus 2017, 5, 456-468.

12. Merriam-Webster. Dictionary. 2022. Available online: https://www.merriam-webster.com/dictionary (accessed on 19 April 2021).

13. Graff, H. The 'Problem' of Interdisciplinarity in Theory, Practice, and History. Soc. Sci. Hist. 2016, 40, 775-803. [CrossRef]

14. Finnish National Agency for Education. National Core Curriculum for Basic Education; Finnish National Agency for Education: Helsinki, Finland, 2014.

15. Finnish National Agency for Education. National Core Curriculum for General Upper Secondary Schools; Finnish National Agency for Education: Helsinki, Finland, 2015.

16. Finnish National Agency for Education. National Core Curriculum for General Upper Secondary Schools; Finnish National Agency for Education: Helsinki, Finland, 2019.

17. Teachers Climate Guide. Geography. Available online: https://teachers-climate-guide.fi/geography/ (accessed on 19 April 2021).

18. Leiserowitz, A.; Smith, N.; Marlon, J.R. American Teens' Knowledge of Climate change. In Proceedings of the Yale Project on Climate Change Communication; Yale University: New Haven, CT, USA, 2011; Available online: http: / / www.ourenergypolicy.org/wpcontent/uploads/2013/05/American-Teens-Knowledge-of-Climate-Change.pdf (accessed on 19 April 2021).

19. Shepardson, D.P.; Niyogi, D.; Choi, S.; Charusombat, U. Seventh grade students' conceptions of global warming and climate change. Environ. Educ. Res. 2009, 15, 549-570. [CrossRef]

20. Taber, F.; Taylor, N. Climate of concern: A search for effective strategies for teaching children about global warming. Int. J. Environ. Sci. Educ. 2009, 4, 97-116.

21. Chen, X. Why do people misunderstand climate change? Heuristics, mental models and ontological assumptions. Clim. Chang. 2011, 108, 31-46. [CrossRef]

22. Choi, S.; Niyogi, D.; Shepardson, D.P.; Charusombat, U. Do earth and environmental science textbooks promote middle and high school students' conceptual development about climate change? Textbooks' consideration of students' misconceptions. Bull. Am. Meteorol. Soc. 2010, 91, 889-898. [CrossRef]

23. Ratinen, I. Primary student teachers' climate change conceptualization and implementation on inquiry-based and communicative science teaching: A design research. In Jyvaäskylaä Studies in Education, Psychology and Social Research; University of Jyväskylä: Jyväskylä, Finland, 2016; p. 555.

24. Sterman, J.D. Communicating climate change risks in a skeptical world. Clim. Chang. 2011, 108, 811. [CrossRef] 
25. Bråten, I.; Britt, M.A.; Strømsø, H.I.; Rouet, J.-F. The role of epistemic beliefs in the comprehension of multiple expository texts: Toward an integrated model. Educ. Psychol. 2011, 46, 48-70. [CrossRef]

26. Lehtonen, A.; Salonen, A.O.; Cantell, H. Climate change education: A new approach for a world of wicked problems. In Sustainability, Human Well-being, and the Future of Education; Cook, J.W., Ed.; Palgrave Macmillian: London, UK, 2018 ; pp. 339-374. ISBN 978-331-978-579-0. [CrossRef]

27. Tani, S.; Hilander, M.; Leivo, J. Ilmastonmuutos lukion opetussuunnitelmissa ja maantieteen oppikirjoissa. Ainedidaktiikka 2020, 4, 3-24. [CrossRef]

28. Brouziyne, Y.; Abouabdillah, A.; Hirich, A.; Bouabid, R.; Zaaboul, R.; Benaabidate, L. Modeling sustainable adaptation strategies toward a climate-smart agriculture in a Mediterranean watershed under projected climate change scenarios. Agric. Syst. 2018, 162, 154-163. [CrossRef]

29. Jeong, J.S.; González-Goómez, D.; Cañada-Cañada, F. Prioritizing elements of science education for sustainable development with the MCDA-DEMATEL method using the flipped e-learning scheme. Sustainability 2019, 11, 3079. [CrossRef]

30. Jeronen, E. Sustainable Education. In Encyclopedia of Sustainable Management; Idowu, S., Schmidpeter, R., Capaldi, N., Zu, L., Del Baldo, M., Abreu, R., Eds.; Springer: Cham, Switzerland, 2022. [CrossRef]

31. Sterling, S. Sustainable education-Towards a deep learning response to unsustainability. In Policy E Practice. A Development Education Review; Spring: Belfast, UK, 2008; pp. 63-68.

32. Prabakaran, M. Historical appropriation of epistemological values: A goal ahead for higher education. High. Educ. Future 2020, 7, 67-81. [CrossRef]

33. Abduganiev, O.I.; Abdurakhmanov, G.Z. Ecological education for the purposes sustainable development. Am. J. Soc. Sci. Educ. Innov. 2020, 2, 280-284. [CrossRef]

34. Moore, J. Is Higher Education Ready for Transformative Learning? A Question Explored in the Study of Sustainability. J. Transform. Educ. 2005, 3, 76-91. [CrossRef]

35. UNESCO (United Nations Educational, Scientific and Cultural Organization). Education for Sustainable Development. A Roadmap. \#ESDfor 2030. Paris, France. 2020. Available online: https://www.gcedclearinghouse.org/sites/default/files/ resources/200782eng.pdf (accessed on 20 July 2021).

36. UNFCCC. United Nations Framework Convention on Climate Change. 1992. Available online: https://unfccc.int/resource/ docs/convkp/conveng.pdf (accessed on 20 November 2021).

37. UNESCO (United Nations Educational, Scientific and Cultural Organization). Education for Sustainable Development and Climate Change. Policy Dialogue 4. 2009. Available online: http://unesdoc.unesco.org/images/0017/001791/179122e.pdf (accessed on 20 November 2021).

38. UNESCO (United Nations Educational, Scientific and Cultural Organization). The UNESCO Climate Change Initiative: Climate Change Education for Sustainable Development. Paris: UNESCO. 2010. Available online: https://unesdoc.unesco.org/images/ 0019/001901/190101E.pdf (accessed on 20 November 2021).

39. UNESCO (United Nations Educational, Scientific and Cultural Organization); UNFCCC (United Nations Framework Convention on Climate Change). Action for Climate Empowerment: Guidelines for Accelerating Solutions Through Education, Training and Public. Paris: UNESCO and UNFCCC. 2016. Available online: https://unfccc.int/sites/default/files/action_for_climate_ empowerment_guidelines.pdf (accessed on 20 November 2021).

40. Hindley, A.; Wall, T. A unifying, boundary crossing approach to developing climate literacy. In Implementing Sustainability in the Curriculum of Universities: Teaching Approaches, Methods, Examples and Case Studies; Leal Filho, W., Ed.; Springer: London, UK, 2017; pp. 263-278. ISBN 978-331-970-280-3.

41. Monroe, M.; Plate, R.R.; Oxarart, A.; Bowers, A.; Chaves, W.A. Identifying effective climate change education strategies: A systematic review of the research. Environ. Educ. Res. 2017, 25, 791-812. [CrossRef]

42. Kagawa, F.; Selby, K. (Eds.) Education and Climate Change: Living and Learning in Interesting Times; Routledge: New York, NY, USA, 2010; ISBN 978-041-564-915-5.

43. Lewis, E.; Mansfield, C.; Baudains, C. Ten tonne plan: Education for sustainability from a whole systems thinking perspective. Appl. Environ. Educ. Commun. 2014, 13, 128-141. [CrossRef]

44. Draper, F. A proposed sequence for developing system thinking in a grades 4-12 curriculum. Syst. Dyn. Rev. 1993, 9, 207-214. [CrossRef]

45. Salonen, A.O.; Bardy, M. Ekososiaalinen sivistys herättää luottamusta tulevaisuuteen. Aikuiskasvatus 2015, 35, 4-15. [CrossRef]

46. Dragoni, L.; Oh, I.-S.; Vankatwyk, P.; Tesluk, P.E. Developing executive leader: The relative contribution of cognitive ability, personality, and the accumulation of work experience in predicting strategic thinking competency. Pers. Psychol. 2011, 64, 829-864. [CrossRef]

47. Macy, J. Working through environmental despair. In Ecopsychology: Restoring the Earth, Healing the Mind; Roszak, T., Gomes, M.E., Kanner, A.D., Eds.; Sierra Club: San Francisco, CA, USA, 1995; pp. 240-269. ISBN 087-156-406-8.

48. Norgaard, K.M. Living in Denial: Climate Change, Emotions, and Everyday Life; MIT Press: Cambridge, MA, USA, 2011; ISBN 978-026-201-544-8.

49. Pihkala, P. Climate Anxiety; MIELI Mental Health: Helsinki, Finland, 2019.

50. Stoknes, P.E. What We Think about When We Try Not to Think about Global Warming: Toward a New Psychology of Climate Action; Chelsea Green Publishing: London, UK, 2015; ISBN 978-160-358-583-5. 
51. Jeronen, E.; Jeronen, J.; Raustia, H. Environmental education in Finland-A case study of environmental education in nature schools. Int. J. Environ. Sci. Educ. 2009, 4, 1-23.

52. Schreiner, C.; Henriksen, E.K.; Kirkeby Hansen, P.J. Climate education: Empowering today's youth to meet tomorrow's challenges. Stud. Sci. Educ. 2008, 41, 3-49. [CrossRef]

53. Stevenson, R.B.; Nicholls, J.; Whitehouse, H. What is climate change education? Curric. Perspect. 2017, 37, 67-71. [CrossRef]

54. Saloranta, S. The importance of a school's culture in implementing Education for Sustainable Development in Basic Education grades 1-6 schools. In Studies in Education, 14; Faculty of Educational Sciences, University of Helsinki: Helsinki, Finland, 2017; (In Finnish, Abstract in English).

55. Tabi, A. Does pro-environmental behaviour affect carbon emissions? Energy Policy 2013, 63, 972-981. [CrossRef]

56. Wei, J.; Chen, H.; Long, R. Is ecological personality always consistent with low-carbon behavioral intention of urban residents? Energy Policy 2016, 98, 343-352. [CrossRef]

57. Paco, A.; Lavrador, T. Environmental knowledge and attitudes and behaviours towards energy consumption. J. Environ. Manag. 2017, 197, 384-392. [CrossRef]

58. Jakučionytè-Skodienè, M.; Liobikienè, G. The Changes in Climate Change Concern, Responsibility Assumption and Impact on Climate-friendly Behaviour in EU from the Paris Agreement Until 2019. Environ. Manag. 2022, 69, 1-16. [CrossRef] [PubMed]

59. Boon, H. Pre-service teachers and climate change: A stalemate? Aust. J. Teach. Educ. 2016, 41, 39-63. [CrossRef]

60. Lombardi, D.; Sinatra, G.M. Emotions about teaching about human-induced climate change. Int. J. Sci. Educ. 2012, 35, 167-191. [CrossRef]

61. Monroe, M.C.; Oxarart, A.; Plate, R.R. A role for environmental education in climate change for secondary science educators Appl. Environ. Educ. Commun. 2013, 12, 4-18. [CrossRef]

62. Robinson, Z. Teaching climate change in higher education: Barriers and opportunities. In Pedagogy of Climate Change: An Introduction; Haslett, S., France, D., Gedye, S., Eds.; Higher Education Academy: York, UK, 2011; pp. 36-50. ISBN 978-184-102-273-4.

63. Nganga, L.; Roberts, A.; Kambutu, J.; James, J. Examining pre-service teachers' preparedness and perceptions about teaching controversial issues in social studies. J. Soc. Stud. Res. 2020, 44, 77-90. [CrossRef]

64. Chang, C.-H.; Pascua, L. Singapore students' misconceptions of climate change. Int. Res. Geogr. Environ. Educ. 2016, 25, 84-96. [CrossRef]

65. Ratinen, I.; Uusiautti, S. Finnish students' knowledge of climate change mitigation and its connection to hope. Sustainability 2020, 12, 2181. [CrossRef]

66. Yli-Panula, E.; Laakkonen, E.; Vauras, M. High-school students' topic-specific epistemic beliefs about climate change: An assessment-related study. Educ. Sci. 2021, 11, 440. [CrossRef]

67. Leiserowitz, A.; Maibach, E.; Roser-Renouf, C.; Smith, N. Climate change in the American mind: Americans' global warming beliefs and attitudes. In Yale Project on Climate Change Communication; Yale University and George Mason University: New Haven, CT, USA, 2010.

68. Poortinga, W.; Spence, A.; Whitmarsh, L.; Capstick, S.; Pidgeon, N.F. Uncertain climate: An investigation into public scepticism about anthropogenic climate change. Glob. Environ. Chang. 2011, 21, 1015-1024. [CrossRef]

69. Cano, F. Epistemological beliefs and approaches to learning: Their change through secondary school and their influence on academic performance. Br. J. Educ. Psych. 2005, 75, 203-221. [CrossRef]

70. Mason, L.P.; Boscolo, M.; Tornatora, C.; Ronconi, L. Besides knowledge: A cross-sectional study on the relations between epistemic beliefs, achievement goals, self-beliefs and achievement in science. Instr. Sci. 2013, 41, 49-79. [CrossRef]

71. Cantell, H.; Tolppanen, S.; Aarnio-Linnanvuori, E.; Lehtonen, A. Bicycle model on climate change education: Presenting and evaluating a model. Environ. Educ. Res. 2019, 25, 717-731. [CrossRef]

72. Reid, A. Climate change education and research: Possibilities and potentials versus problems and perils? Environ. Educ. Res. 2019, 25, 767-790. [CrossRef]

73. Finnish National Agency for Education. National Core Curriculum for Basic Education for adults. In Regulations and Quidelines; PunaMusta Oy: Helsinki, Finland, 2017.

74. Finnish Education in a Nutshell. 2018. Available online: https://www.oph.fi/en/statistics-and-publications/publications/ finnish-education-nutshell (accessed on 19 April 2021).

75. The National Board of Education. The Finnish National Core Curriculum for Upper Secondary School; Vammalan Kirjapaino Oy: Vammala, Finland, 2003; ISBN 952-13-1833-3.

76. Tuomi, J.; Sarajärvi, A. Laadullinen Tutkimus ja Sisällönanalyysi. 204 s; Kustannusosakeyhtiö Tammi: Helsinki, Finland, 2018.

77. The Finnish National Board on Research Integrity TENK. The Ethical Principles of Research with Human Participants and Ethical Review in the Human Sciences in Finland. In Finnish National Board on Research Integrity TENK Guidelines; Finnish National Board on Research Integrity TENK: Helsinki, Finland, 2019.

78. Demirkaya, H. The understandings of global warming and learning styles: A phenomenographic analysis of prospective primary school teachers. Educ. Sci. Theor. Pract. 2008, 8, 51-58.

79. Kärnä, P.; Hakonen, R.; Kuusela, J. Luonnontieteiden Osaaminen Perusopetuksen 9. Luokalla; Koulutuksen Seurantaraportit, 2; Opetushallitus: Helsinki, Finland, 2012.

80. Saloranta, S.; Uitto, A. Rehtori koulun kestävän kehityksen toimintakulttuurin edistäjänä. Natura 2012, 49, 27-30. 
81. Finnish National Agency for Education. Ilmastovastuun Oppiminen-Visio, Tavoitteet ja Toimenpide-Ehdotukset. Available online: https: / / www.oph.fi/fi/tietoa-meista/ilmastovastuun-oppiminen-visio-tavoitteet-ja-toimenpide-ehdotukset (accessed on 26 October 2020).

82. Pihkala, P. Kuinka käsitellä maailman ongelmia? Traagisuus ja toivo ympäristökasvatuksessa. Ainedidaktiikka 2017, 1, 2-14. [CrossRef]

83. Särkelä, E. Young People's Lifeworld and Everyday Gaographies as a Part of Geography Teaching. Empathy-Based Stories and Photography as Methods to Research Young People's Reflections on the Global Generations and the State and Future of the world. Helsinki Studies in Education, 111. Ph.D. Dissertation, University of Helsinki, Helsinki, Finland, 2021.

84. Aarnio-Linnanvuori, E. Ympäristö Ylittää Oppiainerajat-Arvolatautuneisuus ja Monialaisuus Koulun Ympäristöopetuksen Haasteina (Environment Crosses Subject Borders-Value-Ladenness and Interdisciplinarity as Challenges for Environmental Education at School). Ph.D. Dissertation, Helsingin Yliopisto, Helsinki, Finland, 2018.

85. Raath, S.; Hay, A. Self-efficacy: A South African case study on teachers' commitment to integrate climate change resilience into their teaching practices. Cogent Educ. 2016, 3, 1264698. [CrossRef]

86. Wolff, L.-A. Nature and Sustainability: An Educational Study with Rousseau and Foucault; Lambert Academic Publishing: Saarbrücken, Germany, 2011.

87. Kollmuss, A.; Agyeman, J. Mind the gap: Why do people act environmentally and what are the barriers to pro-environmental behavior? Environ. Educ. Res. 2002, 8, 239-260. [CrossRef]

88. Liu, S.; Roehrig, G. Exploring science teachers' argumentation and personal epistemology about global climate change. Res. Sci. Educ. 2017, 49, 173-189. [CrossRef]

89. Metsämuuronen, J. Laadullisen Tutkimuksen Perusteet, 3rd ed.; International Methelp Oy: Helsinki, Finland, 2008; ISBN 978-952537-224-3.

90. Bråten, I.; Gil, L.; Strømsø, H.I.; Vidal-Abarca, E. Personal epistemology across cultures: Exploring Norwegian and Spanish university students' epistemic beliefs about climate change. Soc. Psychol. Educ. 2009, 12, 529-560. [CrossRef]

91. Christenson, N.; Chang Rundgren, S.-N.; Zeidler, D.L. The relationship of discipline background to upper secondary students' argumentation on socioscientific issues. Res. Sci. Educ. 2014, 44, 581-601. [CrossRef]

92. Rautiainen, M. Keiden Koulu?: Aineenopettajaksi Opiskelevien Käsityksiä Koulukulttuurin Yhteisöllisyydestä. Jyväskylä Studies in Education, Psychology and Social Research 350; Jyväskylän Yliopisto: Jyväskylä, Finland, 2008.

93. Alwin, D.F.; Krosnick, J.A. The reliability of survey attitude measurement: The influence of question and respondent attributes. Sociol. Methods Res. 1991, 20, 139-181. [CrossRef]

94. Chyung, S.Y.; Roberts, K.; Swanson, I.; Hankinson, A. Evidence-based survey design: The use of a midpoint on the Likert scale. Perform. Improv. 2017, 56, 15-23. [CrossRef]

95. Ojala, M. Hope and climate change: The importance of hope for environmental engagement among young people. Environ. Educ. Res. 2012, 18, 625-642. [CrossRef]

96. Trott, C.D. Reshaping our world: Collaborating with children for community-based climate change action. Action Res. 2019, 17, 42-62. [CrossRef]

97. Laal, M.; Ghodsi, S.M. Benefits of collaborative learning. Procedia-Soc. Behav. Sci. 2012, 31, 486-490. [CrossRef] 